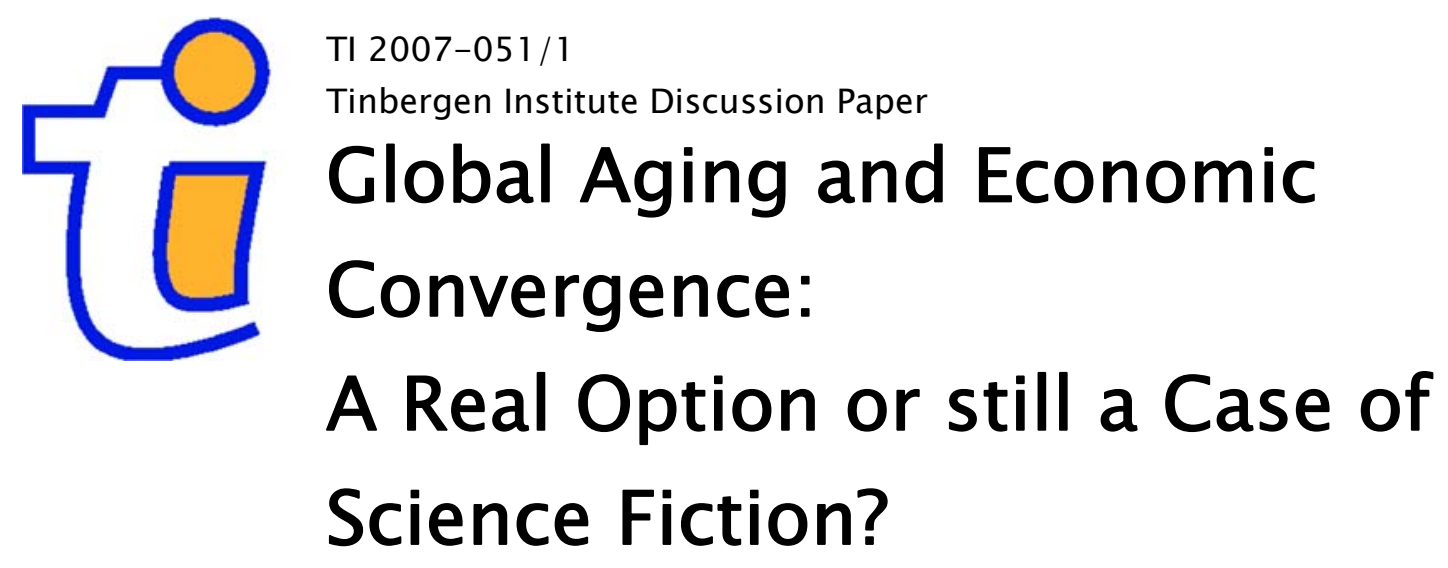

Hendrik P. van Dalen

Netherlands Disciplinary Demographic Institute (NIDI), The Hague, and

Department of Economics, Erasmus University Rotterdam, Tinbergen Institute. 


\section{Tinbergen Institute}

The Tinbergen Institute is the institute for economic research of the Erasmus Universiteit Rotterdam, Universiteit van Amsterdam, and Vrije Universiteit Amsterdam.

Tinbergen Institute Amsterdam

Roetersstraat 31

1018 WB Amsterdam

The Netherlands

Tel.: $\quad+31(0) 205513500$

Fax: $\quad+31(0) 205513555$

Tinbergen Institute Rotterdam

Burg. Oudlaan 50

3062 PA Rotterdam

The Netherlands

Tel.: $\quad+31(0) 104088900$

Fax: $\quad+31(0) 104089031$

Most TI discussion papers can be downloaded at http:/ /www.tinbergen.nl. 


\title{
Global Aging and Economic Convergence: A Real Option or Still a Case of Science Fiction?*
}

\author{
Hendrik P. van Dalen
}

Netherlands Interdisciplinary Demographic Institute (NIDI)

P.O. Box 11650

NL-2502 AR The Hague

The Netherlands

Tel: +31 703565237

Email: dalen@nidi.nl

Erasmus University Rotterdam

Department of Economics and Tinbergen Institute

P.O. Box 1738

NL-3000 DR Rotterdam

The Netherlands

Email: vandalen@few.eur.nl

July 2, 2007

\begin{abstract}
:
How does global aging affect the convergence in global economic development? Both the developing and developed world will be characterized for the coming decades by aging populations. Changes in the age distribution of a population are an important determinant of economic performance as they affect wealth accumulation and dependency burdens, yielding a demographic dividend of extra growth. During the twenty years from 1975 to 2005 Europe and the US have benefited from a strong demographic dividend. However, in the decades to come this effect will be reversed and the driving force behind the wealth of nations has to be sought elsewhere. Africa and, to some extent, India might benefit from the demographic dividend. However, this potential growth phase may well disappear if supporting conditions for growth are absent. Large-scale migration is not expected to be a sustainable solution to unbalanced global economic developments. Remittances, Foreign Direct Investment (FDI) and Official Development Assistance (ODA) will remain necessary capital flows for the developing world in the near future. Remittances offer no structural solution to reduction of poverty as these funds flow to a selective group of families and are allocated generally to consumption rather than to investment purposes. Migration of a temporary nature in conjunction with offshore outsourcing of services and production may offer a solution for the dilemmas of population and development, which OECD donors face in offering development assistance and designing immigration policy.

* This paper builds on and extends an unpublished essay written as part of the Walter Line Initiative of the European Parliament, financed with financial support of the European Commission. Comments on earlier versions of the paper by Nico van Nimwegen, Frans Willekens, Jörgen Mortensen are gratefully acknowledged.
\end{abstract}




\section{Introduction}

Understanding the nexus between population and development is almost like the quest for the Holy Grail for both academic scholars and policy makers. In highly developed countries, the aging of populations puts welfare states to the test since many social security and pension arrangements are built on assumptions of fixed age distributions in schooling, work and retirement; assumptions that run counter to practice. Politicians are facing the challenge to reform or build welfare states that are both 'aging'-proof and that offer the incentives to increase productivity and welfare of current and future generations. On the other side of the globe - in the less developed countries - the high rates of fertility, the relatively rapid increase in life expectancy, together with the threat of an AIDS-pandemic offer the biggest challenges. High rates of fertility could threaten sustainable development. The AIDS-pandemic is in itself a human tragedy but which constitutes also a catastrophe that destroys human capital, capital that is essential for developing countries to escape from the poverty trap and which brings fertility rates in line with preferred rates (Ross et al., 2005).

Many western countries are aware that demographic developments both at home and in neighboring countries or regions have become of major importance for the welfare of citizens. Therefore, a global view on demographic developments is slowly replacing the more common autarky view on demographic developments. The presence of communicable diseases, the large-scale legal and illegal migration flows, the changing division of labor in the world all make one wary of the fact that views of 'splendid isolation' will not suffice and in this particular sense the world has become a 'smaller place'. This process has been stimulated by the internationalization and integration of markets for goods, labor, capital and ideas and the increasing recognition of the importance of global public goods (see Kaul et al., 2003). Amidst these developments the task of disentangling the consequences of demographic transitions and aging processes and their impact on policy remains a difficult task because unambiguous and universal conclusions how economy and demography interact are hard to reach at this point.

This paper offers a perspective on the issues of global aging and convergence of development by first presenting some relevant stylized facts and forecasts of population growth and aging up to 2050 around the world (section 2). The predictions made rely heavily on those made by the UN (2004), not because they offer superior predictions, but primarily because the UN projections are the focal point in discussing demographic futures worldwide and as Demeny (2004, p. 513) stresses - albeit with respect to the UN long-range projections - they offer its users "a way to think about coming demographic developments: a frame of 
reference that users must fill with substance.” The substance offered focuses on three pertinent issues: (1) do global developments in fertility and mortality lead to a convergence or divergence of economic development? (in section 3); (2) how does migration affect the process of convergence? (Section 4); and (3) what role is there for population and development assistance amidst other international capital flows and international trade in goods and services? (Section 5). Section 6 concludes this paper with a summary and perspective discussing the likelihood of a demographically divided world.

\section{Stylized Facts of Global Aging and Convergence}

During the course of the latter half of the twentieth century two salient features have determined global demographic developments: the increase in life expectancy and the sharp drop in fertility.

\section{Mortality}

To start with the first stylized fact of demographic change, the increase in life expectancy has occurred both developing and developed parts of the world. The most notable element of this development is the pronounced reduction in the gap between the most developed and the less developed countries. For instance, male life expectancy at birth for the period 1950-2000 increased by seven years in the more developed countries and a staggering twenty years in the less developed countries. What lies behind this strong catch up in increased life expectancy in developing countries is the improvement of reproductive health, thereby lowering the infant mortality rate and the mortality rate of women who gave birth to a child. This development in life expectancy is in marked contrast with the developed world where the increased life expectancy is primarily concentrated at the end of the human life span (see Lee and Tuljapurkar, 1997). For an understanding of economic and social consequences this stylized fact is important as the developing world has added years during the most productive stage of the human life course whereas in the developed world the added years were predominantly to be found in the retirement stage.

\section{HERE FIGURE 1}

For the next fifty years life expectancy gains are predicted to be relatively small (see Figure 1), but again the less developed world is expected to catch up with the more developed world 
and in that respect population aging will not be a typical Western phenomenon but will occur in both developing and developed countries.

\section{Fertility}

The perspective of an aging world will be even more pronounced if we take a look at fertility developments over the past years and cast an eye to the decades to come. Fertility started to drop sharply around 1970 (see Figure 2) in both more developed and less developed countries but with a sharper drop in the latter group, presumably attributable to a wider knowledge and distribution of contraceptive means. The only exception to this rule is Africa, a continent that is expected to maintain a level of fertility above the level compatible with a stable population. As shown in Figure 2, fertility in Africa although converging towards that of other regions in the world, is projected nevertheless to remain at some 2.5 even in 2050 while in Asia, the Americas and Europe fertility is projected to converge towards 1.9, corresponding to a falling population in the long run (assuming a gradual leveling off of life expectancy). There are, however, provisos which could shed a different light on this long term convergence process. These forecasts depend to a large extent on how fertility preferences and control develop.

\section{HERE TABLE 1}

To explore the latter force one can be both pessimistic and optimistic about fertility control results attained. Substantial progress has been achieved in satisfying the demand for modern contraceptive use (male and female sterilization, IUD, pill and condom) in developing countries. The demand for contraceptives, as presented in Table 1 is defined as the sum of actual use of contraceptives and the unmet need ${ }^{1}$ for them and to gain an impression of the level of satisfied demand the actual use is simply devided by the demand, for five wealth classes. The general impression is that the poorest persons have the least part of their demand satisfied by contraceptive use, but over time each quintile and each region has shown improvement. Africa, in particular Sub-Saharan Africa remains, however, a region of demographic risk in many respects. In this respect one can see why Cleland and Sinding (2005) stress the need for further support for family planning programs in Sub-Saharan

\footnotetext{
${ }^{1}$ The common definition of unmet need used in Demographic Health Surveys is: Women with unmet need are those who are married/cohabiting, fecund, not using a method, and wish to postpone birth at least two years. Women who are pregnant or amenorrheic have unmet need if they did not want the current pregnancy or recent birth either at that time or at all, but if a contraceptive failure was responsible the woman is treated as having no unmet need.
} 
Africa. The issue of the economic consequences of high fertility rates and unmet need seems to have been swamped by the attention and financial support directed at the HIV/AIDS pandemic, whereas common sense dictates that reproductive health care and prevention of HIV/AIDS go hand in hand.

Fertility preferences are not fixed and contraceptive technology is not the only driving force behind fertility developments. As Bongaarts (2003) shows, based on a set of demographic health surveys, the level of education matters considerably in attaining levels of fertility. This finding is corroborated by regression results with the World Values Survey in Table 2, explaining the number of children raised by married or ever married women. Age group differences exist, which could signify that fact that preferences of cohorts differ as well as the fact that timing of births may have been shifted to later periods in life. The most important effects are to be traced in the strong educational effects, especially in non-OECD countries and the candidate countries of the EU (notably Turkey), the weak income effects and the non-negligible effects which religion exerts in affecting fertility levels. Especially in Western countries the secularization of everyday life seems to have had a profound influence on fertility developments. The relatively small effect of religion in countries outside the OECD is perhaps also a telling sign that fertility preferences are hard wired and changing fertility preferences is a long-term issue.

\section{HERE TABLE 2}

The strong educational effects can have far-reaching consequences. If the educational composition of developing countries does not change the demographic transition as depicted in Figure 2 in developing countries may come to a halt and so will economic convergence.

\section{HERE FIGURE 2}

\section{Aggregate demographic consequences}

Despite a decline during the last decade or so (partly due to the AIDS epidemic) life expectancy in Africa is projected by the UN to resume its rise during the coming decades. In response to both a maintained high level of fertility and some improvement in life expectancy, the Sub-Saharan Africa's population is projected to substantially increase its share in the world population, from about 12.5 percent in 2000, to 17 per cent in 2025 and to 23 per cent in 2050. In other words, while in 1950 only eight persons out of one hundred were living in 
Sub-Saharan Africa, almost a quarter of the world's population will, according to the UN's projections, live in Sub-Saharan Africa. As a result of high (albeit declining) fertility, SubSaharan Africa will account for an even larger share of the world's population of children and youngsters: in the age groups $0-14$ and 15-24 almost 30 percent of the world population is expected to live in Sub-Saharan Africa and this is also expected to be the case for the age group 25-64 whose share will be catching up with the share of the younger age groups, mainly due to the gradual stagnation of the number of persons in the active age groups in the rest of the world.

\section{HERE TABLE 3}

For the world as a whole, the most striking feature of future population trends will be the stagnation of the number of young people in the world coupled with a continued rise in the people in working age and, notably, the number of elderly (see Table 3). Thus, the number of children (0-14 years old) which rose by more than 600 million between 1950 and 1975 (the baby boom) and by 330 million from 1975 to 2000, is projected to rise by only some 80 million between 2000 and 2025 and then to actually decline by close to 80 million over the following twenty-five years. The latter development is a remarkable evolution in demographic history. As a consequence of this event the total number of children in the world in 2050 is expected to be practically the same as in the year 2000: approximately 1.8 billion.

\section{Demography, Economic Growth and Convergence}

How do these two dominant trends - a decline in fertility and an increase in life expectancy affect the world economy? The views concerning the effect of population growth and the age distribution of the population on economic growth vary over a large spectrum of economic theory and empirical analysis. It is often argued that the rapid population growth has a negative effect on economic growth, but compelling evidence on this point has been rather elusive and subject to an abundance of counterarguments. Since the early 1980s the dominant view has been that population growth neither systematically impedes nor promotes economic growth. More recently, however, evidence has emerged suggesting that changes in the age distribution of a population may be an important determinant of economic performance (Bloom and Williamson, 1998; Lee et al., 2003). In particular, the pattern of saving and consumption may vary over the life cycle and it is the relative size of young, working-age and retired persons which determine aggregate saving and consumption of a population. 
Demographic transitions can affect economic growth by various phases. The age distribution effect of a decline in fertility (frequently termed 'the second demographic transition') will operate first to lower, then to raise, then to lower again the ratio of the economically active population to the total population. The first effect is called the 'burden' phase of a typical demographic transition, whereas the 'gift' phase represents the phase covering the interval during which dependency ratio is lower than the new stationary state.

The latter effect is better known the 'demographic dividend'. Given that the age distribution is determined by fluctuations in fertility, mortality and migration it may consequently be desirable to take account of these factors in an analysis of the effects on economic growth of demographic change. In a more recent study using data for a panel of countries Bloom and Canning (2004) find growth of working-age to total population to have a positive sign and in fact being close to one. They consider this effect to be essentially equivalent to a supply-side boost to the economy. However, Bloom and Canning stress that the condition for this effect to materialize is that the economy is in a position to effectively adapt the demand for labor (and employment) to the fluctuations in supply. In fact, they find that a completely open economy will enjoy nearly twice the growth impact of demographic change as the average country. In addition their results indicate that a country with a closed economy will have no gain from demographic change. Consequently, "the impact of demographic change may be to increase labor supply but how well this extra supply of workers is put to productive employment depends on the economic system and policies being used” (Bloom and Canning, 2004, p. 29). Needless to say, the age composition of the population is only one of the determinants of economic growth.

If we apply these research findings to the case of Western countries or an industrial challenger like China the demographic projections of the potential work force (15-64 years of age) for the next fifty years are not too encouraging. In Europe the work force shows a steady increase in the work force potential up and till 2010 (see Figure 3), after which the work force will steadily decline.

\section{HERE FIGURE 3}

The developments in the United States are less pronounced from 2010 to 2050. The most volatile developments in work force structure can be found in China, where the work force rapidly increased from a low 56 percent of the population to a high point of 73 percent around 2010. The subsequent fall in relative work force size is just as dramatic as the European fall. 
From 2010 to 2050 both countries seem to move in tandem, although the Chinese work force remains two to three percentage points higher. Consequently, during the twenty years from 1970 to 2010 these old and new industrialized countries have benefited from a strong demographic dividend. As far as East Asia is concerned, the demographic dividend over the same period may have been even larger, with the ratio of working-age to dependent population rising from 1.4 to 2.5 or by almost 80 percent, corresponding to some two percentage points per year.

However, in the decades to come the benefits of a growing work force will dissipate and the demographic dividend will turn into a 'demographic hangover'. The driving force behind the wealth of nations has to be sought elsewhere: notably more capital accumulation, more work effort, or more innovation. In their study Bloom and Canning define the workingage population as the sum of the number of persons in the age groups from 15-64. Whether the demographic hangover will materialize depends to a large extent on the ability of developed countries, notably in Europe, to compensate the decline in the ratio to working-age to total population by increasing the effective retirement age and the employment ratio in those age classes. If the past is to offer some guidance in the change in number of working years then the increase in life expectancy will trigger an increase in savings, as Bloom et al. (2003) show for a cross-country panel data set. In other words, people apparently preferred in the recent past to finance an increase in life expectancy by saving extra and certainly not working longer. Most European countries have shown a clear bias towards early retirement and are in the process of redressing this tendency by restructuring the pension policies and increasing personal responsibility in matters of retirement. ${ }^{2}$ The effect of increased longevity will however affect the developed and developing nations not alike. As mentioned earlier, the increase in life expectancy in the industrialized countries derives primarily from adding ages at the end of the life and is expected to have a negative impact on economic growth. The less developed nations which still have (relatively) high infant mortality rates may expect to see an increase in life expectancy by adding more youthful years and on that account the longevity increase in these countries can offer a stimulus to economic growth (see Boucekkine et al., 2002).

According to the United Nations’ demographic projections, both Europe and East Asia can be expected to experience a pronounced decline in the ratio of working-age to dependent

\footnotetext{
${ }^{2}$ Of course, there is also the third option to increase technical change or as the 'accountants of economic growth' call it 'total factor productivity', the increase in productivity that cannot be ascribed to increased accumulation of production factors, like land, capital and labor.
} 
population over the coming decades, from 2.3 to 1.4 for Europe and from 2.5 to 1.5 for East Asia. In contrast, South Asia and Sub-Saharan Africa are now expected - alone among the large regions of the world - to experience an increase in the ratio of working-age to dependent population. In the case of the entire African continent (see Figure 3) the work force started to rise around 1990 and that around 2040 Africa is expected to have the highest work force potential (measured by the ratio of potential work force to the total population). The purely demographic developments provide only a broad indication of the potential developments while the actual outcome will undoubtedly result from the interaction of those factors with economic and social policy.

Population growth is not the only driving force of economic growth. Bloom and Williamson (1998) showed in a long-term perspective how demographic transition leads to speeding up and slowing down of economic growth, but in the end the fundamental driving forces underneath the wealth of nations are determined by (human and physical) capital accumulation, international trade and technical progress. And on that count, the empirics of economic growth do not seem to lead on to think that in the long run economies will converge. Sala-i-Martin (1996) shows that the cross-country distribution of global GDP between 1960 and 1990 did not shrink, and that poor countries have not grown faster than rich

countries. The best description of global economy seems to be a process of club convergence: within clubs of relatively homogenous countries there is a process of convergence, but between the clubs the process is marked by a process of divergence. A similar interpretation but with a far longer time horizon is provided by Maddison (2005). Table 4 presents evidence that over five hundred years time where most Western continents seem to converge and follow a similar growth pattern. Regions such as Latin America, Eastern Europe and notably Africa are structurally lagging behind.

\section{HERE TABLE 4}

The lessons of economic growth suggest that diverging demographic developments play some role in economic divergence but to understand diverging growth histories more fully differences in technological progress, international specialization, capital accumulation and social infrastructure have proven to be far more important (Hall and Jones, 1999). 


\section{Migration and Convergence}

The analysis of global aging has left out the third element of demographic accounting: migration. Migration is and always has been the most difficult element of population growth to predict if not to register the stocks and flows of people moving across country boundaries. Furthermore, migration is sometimes presented as the cure-all for aging or declining populations. United Nations (2000) counterfactuals of replacement migration on this point are a case in point. With respect to showing the forces of aging the counterfactuals serve their purpose. However, as realistic policy options the calculations are not very illuminating as they offer a mechanical projection exercise and ignore social or economic mechanisms that drive migration. For instance, for the EU as a whole almost a million immigrants per year would be required to keep the EU population constant over the period up to 2050. Furthermore, more than one and a half million immigrants per year would be required to ensure a constant working-age population. The latter figure corresponds to about five times the level of annual net immigration assumed in Eurostat's 2004 baseline projection. Consequently, only an unlikely level of immigration could thus fill the demographic gap caused by the aging of the EU population. Exercises such as those performed by the UN (2000) are therefore best characterized by the term coined by Coleman (2000) "demographism”: solving a problem by the internal logic of the demographic accounting framework. Migration is potentially a strong force but not for the mechanical reasons of attaining a constant population or age structure. Below the current and future state of the migration force will be reviewed.

\subsection{Current State of Migration}

Migration could potentially speed up the economic convergence process. In standard migration theory people will move to take advantage of wage differences across countries or regions. The inflow of people will affect relative returns in destination and source regions and hence bring about a convergence of living standards. In theory, mobility of labor can bring about the same effect as mobility of capital. The difference is, of course, that whenever people move and settle permanently in another country their financial assets will move as well and thereby affect the capital-labor ratio in both the country of destination and source. An even bigger difference why trade in labour differs markedly from trade in capital or goods is of course the fact that people have values and preferences which goods and capital lack. As the German writer Max Frisch remarked about the ‘Gastarbeiter' (i.e. temporary 'guest' workers) 
triggered by strong German labour demand in the 1960s and 1970s: "Wir haben Arbeitskräfte gerufen, und es sind Menschen gekommen.”3

There are three reasons why migration will not have a substantial beneficial effect on attaining economic convergence.

1. Immigration restrictions. First of all, migration is not free to move.The welfare costs of these restrictions are large, thereby implicitly suggesting how inefficient current restrictive immigration policies are. Hamilton and Walley (1984) were the first to show that the effiency gains from free migration for the world at large could be gigantic, varying from US\$ 4.7 to US\$ 16 trillion, when world GDP was US\$ 7.82 trillion. Moses and Letnes (2005) and Iregui (2005) have refined the analysis by paying attention to adjustment and transaction costs, which toned down the enormous welfare gains of Hamilton and Walley, but by any standard their calculated gains remain enormous. The tacit assumption made in these counterfactual studies is that when immigration restrictions are removed migrants will flow to wherever there the skill price to human capital is higher. The image of a seamless world in which all migrants move from developing countries to developed countries does not ring true and this brings us to the second reason why migration is not expected to be a solution to divergence:

2. Home bias in migration. Just like international trade and capital investments are led by a strong 'home bias', so is the movement of people. With hindsight we have to face the fact that most migration occurs close to home and a substantial closing of the income gap is not very likely. Migrants are by and large not the globetrotters textbooks lead us to believe. The UN reported in 2000 that 175 million people live in a country other than where they were born. Of these 175 million migrants some 15 million are refugees, 14 million acquired citizenship of their new country of residence and of 8.5 million people their country of origin is unknown. For the remaining migrants the OECD has information and this is presented in Table 5. Migrants stay mostly within their continent of birth. The only exception to this rule is Latin America where the bulk of emigrants (primarily from Mexico and the Caribbean) move to the United States.

\section{HERE TABLE 5}

\footnotetext{
${ }^{3}$ Translation: "We have called for labour and we received people."
} 
3. Labor quality of immigrants. A third reason which has to be kept in mind, is that the quality of immigrants in terms of human capital has not been constant over time and developed countries in particular Europe and the United States have encountered an increase in unskilled immigrants (Hatton and Williamson, 2004). In the recent past the composition of immigrants heading towards the United States was primarily European, but due to changing immigration policies the composition of immigrants leads to a growing group of people who do not catch up in terms of wage income (Borjas, 1999). The conclusion reached by Borjas is not without qualifications and Schultz (1998) gives a critical overview where the pitfalls arise in interpreting this type of research. Integration in the labor force can be defined in dimensions of education, productivity, wage growth, labor force participation or literacy and with each dimension the evaluation changes. Perhaps the conclusion of Schultz is worth mentioning as he states that "The decrease in average education of the immigrant population entering the United States is probably less important than the growing heterogeneity of immigrants, with a substantial inflow of immigrants who are both relatively well educated (beyond college) and poorly educated (less than high school).” (Schultz, 1998: 249) An extra pitfall may perhaps be the fact that most conclusions about the quality of immigration are based on the US experience. This may be overturned in the future as gradually the European experience with large-scale immigration cristallizes and evidence becomes available as European states reluctantly have adapated to the status of immigration country and started collecting data (cf. Zimmermann, 2005). Quite a number of European countries (see Boeri et al., 2002) has to deal with faltering integration process in which (North) Africans and Asian immigrants dominate the policy agenda of most European governments in which not only the economic integration seems to matter but also cultural integration. For a long time the process of integration seemed to work, but the early immigrants in Western Europe were either immigrants from old colonies or immigrants from the Mediterranean side of Europe (Spain, Portugal, Greece, Italy) who shared the same European values. The current immigration flow within Europe triggers anti-immigration sentiments which hinder immigration policy reforms. Such sentiments are in line with the labor market position people have: the higher skilled or educated are generally pro-immigration in high-income countries, whereas the lower educated are more averse to immigration (Mayda, 2004, Chiswick and Hatton, 2002, Van Dalen and Henkens 2005). 


\subsection{Future Perspectives on Migration}

Migration flows have mainly been concentrated within the continent of birth (see Table 5).

The ultimate question for the future is whether this pattern will change. There are three reasons to expect that the future will differ:

1. Great expectations. The biggest driving force behind migration is traditionally the size of the divergence in skill prices between sending and receiving countries. Hatton and Williamson (2003) see parallels in fundamental driving forces between Europe of the nineteenth century and Africa today. Especially for Sub-Saharan Africa the effects are strong because of the poor economic conditions of the countries in question. Hatton and Williamson (2003) note a striking resemblance: earlier estimates for European countries before World War I showed that a rise in the foreign to home wage ratio by 10 percent raised gross European emigration in the late nineteenth century by 0.7 per thousand in the short run and 1.3 per thousand in the long run. For a set of African countries a similar increase of 10 percent would lead to an out-migration of nearly 1 per thousand. Although African international migration is mostly within low-wage Africa rather than from Africa to the high waged developed world they acknowledge the possibility that the demographic and economic pressure will mount leading more and more to intercontinental emigration. The same phenomenon is acknowledged by Van Dalen, Groenewold and Schoorl (2005) who use emigration survey data to see how large emigration intentions are and what drives these intentions. Emigration intentions are high, oriented towards countries outside Africa, and the most important driving force is the expectation of economic improvement. The only way in which this force can be offset is by catching up. According to Hatton and Williamson (2002, p. 560) emigration follows a life-cyle: as industrial and demographic revolutions take place emigration often rises to a peak before declining. The main driving force behind this life cycle is the wage rate and the easing of the poverty constraint: as real wages increase from a low level at home, emigration rises; but with further wage growth the poverty constraint is no longer of prime importance and the catching up between source and destination begins to cause emigration to decline.

2. Age composition in sending countries. A second important driving force in triggering emigration is the age structure of a population. It is well known from migration research that emigration from developing countries is mainly initiated by young man, primarily single. The prospect of a growing and young population puts extra pressure on the level of emigration as 
they are the more eligible candidates for moving abroad. This prospect of the demographic future is reflected in the projections which show that the age structure of the potential sending countries will remain significantly younger than that of the developed world, which ages quite strongly. If we restrict our attention to developed countries (like the Western Europe and the United States) vis-a-vis less developed and least developed countries, as depicted in Figure 4, in some countries the gap remains constant and in others it widens.

\section{HERE FIGURE 4}

The median age in the more developed countries rises by more than 16 years: from 29 in 1950 to 45.5 in 2050. The pattern is less steep in Western Europe but given the high intitial median age it is still noteworthy, rising from 34.6 to 46.6 years. The median age in less developed countries is, of course, lower due to factors discussed in the previous sections, but the most significant fact to observe is that the gap stays more or less constant and even decreases somewhat at the end of the observation period, when the aging process levels off in the developed world. The most notable candidate region as a region of emigrants is Africa (Helliwell, 2003). The age structure of the African population will be 'young' for decades to come. Hatton and Williamson (2003) predict that an increase of the share of the young by 5 percentage points increases net emigration by 1.3 per thousand.

3. Lower transaction costs. Finally, the fact that transaction costs tied to moving abroad are far lower today than they were a century ago constitutes a sound reason to expect that the character of migration to differ (Chiswick and Hatton, 2002). Moving across state boundaries not only costs less, staying in contact with the country of origin with family and friends is easier through internet and other telecommunication technologies. Existing networks of migrants will also enable migrants to move internationally as the costs of gathering information on a country of destination, settling and finding work will be lower when family and friends are already there. It is well-known acknowleged in both theory and empirics how migrant networks exert a strong influence on international migration flows. There is however, a substantial side-effect because such networks can also lead migrants to choose a destination without considering the fact that the country of destination may be ill-suited for their capabilities or values. Furthermore, badly integrated networks may make migrants vulnerable to labor market shocks as they often find work through their own limited network. 


\section{Implications for the future}

The pressure to emigrate from developing countries, in particular Africa, is already real and will be hard to redress. Migration flows have a life cycle of their own and only if the source country catches up with the regions of destination can one hope for stable and low migration flows (Hatton and Williamson (2002a). Hatton and Williamson (2002b) make the following telling statement in a review of the migration forces in our world of today: "if OECD countries think they have an immigration problem now, they are going to find the future even more challenging." The question is, of course, whether the prime forces that trigger emigration today might also diminish this pressure in the near future. Immigration countries both the traditional immigration countries like the United States and Australia, but also countries in Europe - are grappling with the consequences of immigration and a slower pace of immigration would seem more desirable as the institutions and citizens in most of these countries can adjust to accommodate the inflow of immigrants. As far as one can rely on intentions as predictors of future behavior, the estimation results in Van Dalen et al. (2005) suggest that the emigration pressure will not subside for a considerable time. First of all, it takes time for economic prospects in these African countries to improve and once they have improved closing the gap between African and Western standards of living will prove to be a difficult transition. And secondly, we know from actual migration experience that the transnational networks turn out to have an important effect on emigration decisions. In short, it is these forces - great expectations about economic gains, poverty, and a relatively young age structure - that will stimulate emigration out of Africa for years if not decades to come, whereas the most important countervailing force (strong catching up processes in the African economies) lacks credibility and will probably not affect the expectations of populations in a significant manner for years to come.

Of course, there are uncertainties and gaps in knowledge about the consequences of migration which need to be explored more in full before firm policy conclusions can be reached. Knowledge of the benefits and losses of the brain drain is imperfect and this state of affairs is perhaps obvious because the gains and losses of migration of skilled people will depend on the initial conditions of both the source and destination country and the size of the migration flow. Beine et al. (2003) show that a brain drain can have negative growth effects in countries where the migration rate is substantial and/or the proportion of higher educated is above 5 percent. By contrast, countries with low level of highly skilled and low migration rates benefit from a brain drain. In short, size and structure matters, and when shocks in stocks are too large it puts the resilience of an economy at stake, but doesn't this apply to any 
system? On a more principle level, a brain drain should not be condemned for, as Stark (2004) argues, "migration is conducive to the formation of human capital” (p. 16). Closing borders is bound to weaken incentives to invest in specialized human capital, either because of the classical argument that the division of labor is restricted by the extent of the market or because in some cases the production of knowledge is essentially the production of a global good and restricting the inflow of scientific personel is detrimental to the production of scientific knowledge.

\section{Investing in Population and Development}

Considering the divergence in population and economic development across the world it is hard to believe that this divergence can be resolved by means of flows of migrants from the South settling permanent in the North. The logical alternative for labor flows between regions is capital flows and open trade regimes. Only by investment in human capital, physical capital and social infrastructure, complemented with the removement of trade barriers can one hope for a convergence of economic development. It is often tacitly assumed that once economic development takes off population growth will automatically slow down. Economic growth is, in short, the best contraceptive around. Of course, the relationship between population and development nexus is far more intricate than this simple statement (and at times based on equally simple correlations) would suggest. The causality could go either way and this has troubled and divided policy makers and advisers in the past decades (Merrick, 2002). The economic growth rate as such is a bad indicator of what is going on in a country, just like population growth is an indicator, which sums up various underlying demographic developments. The dynamics of the age structure of a population are far more important as the literature on the demographic dividend suggests (see section 2). But in order for growth to take off more seems to be needed: suitable policies and governance structures that deal with not only with private investment but also with an appropriate health and educational policies, gender inequality and the disruptive effects of ethnic and religious diversity. The realization that these issues matter in constructing policy sheds new light on ineffective policy designs of the past.

With respect to global demographic developments numerous population conferences have been held to diminish rapid population growth and demographic divergence. The early population conferences in Rome (1954), Belgrade (1965), Bucharest (1974) and Mexico (1984) were very much inspired by the looming population explosion. To put it bluntly, the past can be characterized by two subsequent trains of thought: first - during the 1960s and 
1970s - the Malthusian idea that high fertility causes poverty and lowering fertility (by means of family planning programs) is the key to spreading wealth. Second - during the 1980s up to the Cairo conference - the idea that poverty causes high fertility and by stimulating growth and reduction of poverty one will also see a slowdown in population growth by means of a fertility reduction. Fertility decisions were a private decision and hence so was contraception viewed as a private good. Current debates on foreign assistance in population and economic development are more complex than ever as realization has set in that both markets and governments can fail and that issues of gender and religion, which were assumed away in models of development, do play a role in population issues. Provision of contraception or affordable HIV/AIDS treatment are sometimes simply lacking, thereby impairing private choices. And the failure on the side of the government seems to be concentrated in terms of poor governance systems and provision of health care insurance and health care facilities. Furthermore, disappointing development experiences have served as a wake-up call that development aid is no longer an affair which can be dealt with on a bilateral scale, but which apparently entails a coordinated global perspective. However, coordination of collective action is also hindered by the counterproductive behavioral responses to such well-intentioned efforts: countries may save less and invest less prudently in the case they are assured of foreign assistance. The continuous reflection on the efficiency of multilateral organizations is in that respect a tell-tale sign how difficult the organization of development assistance actually is.

In case of population assistance the same themes resound. The agenda of the International Conference on Population and Development (ICPD), signed by 179 governments in 1994 in Cairo was such an initiative and the Millenium Development Goals (MDG) designed in 2000 represent more recent initiatives on a global scale. At present population assistance programs are dominated by US donor contributions allocated to HIV/AIDS projects and the US President's Emergency Plan for AIDS Relief (PEPFAR) to combat HIV/AIDS has led to a strong upsurge in donor funds in recent years (see Figure 5). ${ }^{4}$ With respect to foreign aid, and population assistance programs as envisioned in the Cairo Program of Action, there are two issues which will be the focus of attention in the coming decades in relation to global aging and population growth: (1) The provision of global public

\footnotetext{
${ }^{4}$ The steep increase in the years around the year 1994 is the result of an expanding definition of population assistance: at the ICPD in Cairo it was decided to include reproductive health programs.
} 
goods and the rationale of foreign aid; (2) the power of remittances and other private capital flows in bringing about economic convergence.

\section{HERE FIGURE 5}

\subsection{Designing Global Public Goods and Foreign Aid}

At the most fundamental level of analyzing foreign aid, one has to address the question of the optimal allocation of donor funds. In the past foreign aid was seen as a moral obligation of the West towards the developing world. Foreign aid stems from a solidarity or altruistic motive. Over time observers with a more analytical point of view have stressed the fact that in a globalizing world human action creates cross-border externalities. As Jayaraman and Kanbur (1999: 419) point out "[This view] rests much more on the direct spillovers of the lack of development in poor countries on to the well-being of rich countries.” These externalities or spillover effects are most visible in questions of environment and global warming, population, migration and refugees, defense spending, terrorism, drugs and crime and communicable diseases like HIV/AIDS. In particular the HIV/AIDS epidemic brings policy dilemmas to the fore which were largely absent in debates about foreign aid. The toll of the disease is high and is expected to remain so, despite projected reductions in prevalence. Given the ongoing efforts to find treatments the UN World Population Prospects (2004a) assume a longer average survivorship for people living with HIV than in previous revisions and therefore somewhat lower future mortality levels in HIV-affected countries.

The reason why one has to focus on transfers (such as conventional foreign aid flows) in conjunction with global externalities is that the presence of global externalities implies a set of implicit transfers, which may well replace or neutralize the explicit transfers of donor countries. This is an important insight from the literature on global collective action (Sandler, 2004). To do good for the developing world, e.g. combating global warming, may well imply to start corrective actions in the developed world instead of transferring income to the developing world for taking actions there (Schelling, 1998). In a world where global public goods are important it matters whether the public good is pure or imperfect, what type of technology is used to produce the public good in question, and which country is most efficient in providing the good. Take the case of HIV/AIDS. The development of an effective vaccine and the fundamental research how HIV/AIDS develops is a 'best-shot technology': resources are best accumulated at the point where discovery is likely to occur with the maximum of input. Development of medicine in the US and Europe is best explained by this characteristic. 
However, discovery of a cure for HIV/AIDS also meets the practical side. When a cure has to be implemented the implementation technology is probably a 'weakest link technology': only the smallest provision level determines the public good level. In other words, the level of immunization of the recipient country will determine the global level of infection. The focus of development policy should thus be on improving the recipient's capacity and willingness to implement HIV/AIDS programs. Parallel issues arise in the case of family planning, which comprises a mixture of the research technology of designing better and cost-effective contraceptives (best-shot technology) together with the practical side of implementing such 'technologies' (weakest link technology). Investments in human capital may prove to be a double-edged sword as education not only increases the productivity of people, but it also increases receptivity for reproductive health programs and a convergence to fertility levels that potentially offer a more sustainable economy.

\section{Balanced foreign aid allocation}

The previous discussion revolved around the organization of global collective action. Another issue pertinent to the achievement of the Cairo goals is the allocation of foreign aid to the various elements of the 'population package' made explicit in the so-called Program of Action. At the start of the program family planning and reproductive health seemed to the primary object of attention. But as time progressed the attention switched to the HIV/AIDS and currently more than 80 percent of the donor funds is allocated to this goal (see Table 6). In 199614 percent of the earmarked funds were allocated to HIV/AIDS, and in 2002 this percentage was 61 percent and projections made by NIDI suggest that for the year 200785 percent of funds go to HIV/AIDS.

\section{HERE TABLE 6}

However, as Cleland and Sinding (2005) argue such an allocation is unbalanced as family planning, reproductive health and prevention of HIV/AIDS go hand in hand. Insiders of the family planning movement fear that this is all due to the way the Millennium Development Goals (MDG) have been explicated (Blanc and Tsui, 2005). Family planning and reproductive health care are treated implicitly, whereas the AIDS pandemic receives ample and explicit attention. Within the world of development aid it is clear how things work at the bureaucratic level: “If you're not an MDG, you're not on the agenda. If you're not a line item, you're out 
of the game,” according to Sinding (in Crossette, 2005, p. 77). The deeper reason may well be that religious values still play a large role in allocating money (van Dalen, 2007).

What's worse is that the recent unprecedented rise of HIV/AIDS funds is disrupting fiscal policy and local health care systems, whereas a more balanced investment in reproductive health and HIV/AIDS would make use of the existing infrastructure. The new HIV/AIDS funds are swamping public health budgets, in some cases exceeding 150 percent of the government's total allocation to health care (Lewis, 2005). Too much money must be spent in too short a time. Such a situation, particularly in conditions of extreme poverty and poor governance prevalent in Sub-Saharan Africa, easily results in 'poaching' of health care workers and bureaucrats from other worthy public projects. In short, when public governance systems are weak, these large, but volatile sums of 'easy money’ promote moral hazard in delivering health care (World Bank, 2004b).

\subsection{Will Foreign Capital Bring About Convergence?}

To stop the pressure to emigrate and to alleviate poverty it is of prime importance to design robust public insurance and health systems in developing countries. Catching up with the industralized world would therefore seem like a minimal condition and and influx of private and public capital would make it possible to escape the poverty trap which keeps the least developed countries stuck at low levels of income. The developing countries receive foreign capital flows from a number of sources. Foreign direct investment (FDI) and private (nonFDI) capital flows are traditionally the most important private transactions together with official development assistance (ODA) coming from OECD/DAC members. Private non-FDI capital flows are highly volatile and cyclical and can on that count not be seen as a stable factor in development policy. FDI is a more stable factor but this is hardly a factor that will help countries with a poor social infrastructure (law and order, norms and values, health and education) and weak physical public infrastructure (roads, sewerage, electricity networks). Ideally, development assistance should in principle fill the gap where market failures appear.

\section{Official Development Assistance}

The practice of government intervention is however clouded by numerous problems which increase the transaction costs of correcting market failures. A study by Burnside and Dollar (2002) gives the impression that aid helps as long as it flows to countries with 'good policy environments'. At present the number of studies which shed serious doubts about the effectiveness of foreign aid or multilateral loans are too large to ignore (cf. Barro and Lee, 
2005; Rajan and Subramanian, 2005; Easterly, 2003) and aid seems to be provided more in line with the ideology and preferences of donor governments than the needs of the least developed countries (Alesina and Dollar, 2001, Van Dalen, 2007). The collective action problems of foreign aid - primarily the counterproductive behavioral responses that are tied to the allocation funds and the organization of assistance - are fickle and the search for silver bullet solutions is bound to be misleading. Either complete decentralization or centralization of aid will run into trouble as both options have their specific transaction costs which make the choice between bilateral and multilateral aid or the choice of delivering aid through an NGO or a government department a pragmatic one (i.e. it depends on the costs and benefits of these institutions). One of the drawbacks of ODA or for that matter population assistance is its cyclicality: its tight connection with changes in GDP (IMF, 2005).

\section{Remittances}

Remittances are sometimes seen as a substitute for ODA. As one can see from Figure 6 remittances from migrants have over time become a dominating flow of resources that tops ODA and that is almost at the same level as FDI. According to the World Bank (2004), remittances received by less developed countries totaled 93 billion US dollars in 2002. Although the size of remittance flows is undoubtedly large, evidence of their beneficial effects on development and economic growth is neither substantial nor unambiguous. In a comparative study of 74 less developed countries, Adams and Page (2003) found that remittances have a strong impact on reducing poverty. Similar findings are reported in IMF (2005) where remittances significantly reduce poverty and volatility in output, consumption and investment in the recipient countries.

\section{HERE FIGURE 6}

However, Chami et al. (2005), using panel data from 113 less developed countries, show that remittances have a negative effect on economic growth. These authors suggest that adverse effects on the behavior of those receiving remittances from migrants may be the key to understanding why this form of help hinders economic performance. The effects may be one or more of the following: to work less, save less, restrict efforts to find work, make riskier investments, and, perhaps, signal to other family members staying behind that it would be worthwhile to move abroad and join the remitter. Survey data in African countries (Schoorl et al. 2000) suggest that the allocation of remittances to productive investments is very small. 
Most of the remittances are allocated to daily needs and in that respect one can understand why remittances offer assistance in poverty reduction but are less successful in generating growth and thereby a structural solution to poverty. Furthermore, there are signs noted by Van Dalen, Groenewold and Fokkema (2005) that remittances could potentially trigger new emigration flows either by financing emigration or by signaling to those staying behind that emigration is a profitable undertaking.

Furthermore, we should be wary of the fact that migrants stay mostly within their continent of birth (see Table 5) and remittances generally follow this trend (see Table 7). As one can see the remittances that go to Africa constitute 11 percent of the total amount of 91 billion US dollars that annually crosses borders from migrants to their family and friends. The bulk of remittances goes to people living in Asian countries, but these money transfers also stem from migrants residing in Asian countries.

\section{HERE TABLE 7}

Some have proposed to use migration and the concomitant remittances as a way of development assistance. The numbers presented in Figure 6 reinforce the beliefs of those proponents. Such proposals can be best characterized as a sophisticated form of 'demographism'. The surplus population in developing countries can be used to smooth population aging in the developed world and by doing so remittances will flow to developing countries. An added bonus, so it is thought, is the fact that immigrants generate their own development aid by sending remittances home. Migration used in such an instrumental fashion negates the fact that migration is a free choice, albeit more and more bound by immigration policies restricting entrance.

\section{What might work: outsourcing to return migrants}

The development of offshore outsourcing of production and services may bring private capital flows and migration in line with each other. Ricardo's theory of comparative advantages can, thanks to ICT-technology, become relevant at this point. This theory explains movement in goods and services in terms of the relative costs tied to producing these goods and services. A country exports goods in which it has relative cost advantage and imports those goods in which it has a relative cost disadvantage. However, in applying this theory one should keep in mind the realities of modern-day globalization in which proximity matters in carrying out transactions. The rhetoric of globalization revolves much about the image of a seamless world 
and "the death of distance". As Leamer and Storper (2001) argue, this image is in striking contrast with the empirical regularities reflected in geographical clustering in production:

"The finer the division of labor, the greater are the coordination needs. Routine coordination of standardized intellectual or physical task can be done with 'markets' that can be extended geographically with communication technologies. But complex and unfamiliar coordination of innovative activities requires longterm relationships, closeness and agglomerations.” (p. 643)

In that respect, the alternative of offshore outsourcing may be an option which can comes midway as it offers the potential to make use of the wage differences in the world. Activities that can be outsourced to developing countries may initially be limited to standardized or easiliy codifiable tasks. But more complex services and products may become familiar to those countries through the return of migrants, who not only have human capital abroad but also social capital (i.e. trust and networks). It is thought that through this mechanism Sillicon Valley offered benefits to Indian immigrants who upon return in India could build ict services which benefit many western companies. Amiti and Wei (2005) show that the doomsday fears of developed nations (cf. Drezner, 2004) about the destructive power of service outsourcing are so far not justified. On the contrary, outsourcing is often accompanied by its counterpart insourcing - and the new division of labor enabled by information and communication technology (ICT) is a profitable transaction for both sides. In short, migration and trade go hand in hand the intermediary role is recognized which migrants may play in bringing about long distance trade (cf. Gould, 1994) and the outsourcing of production and services (Helliwell, 2004).

\section{Which Way Out of the Population and Development Conundrum?}

Ever since Malthus published his Essay on Principles of Population it has been custom among outsiders to mark economists as dismal scientists. However, it may well be that the subject - demographic futures - is bound to make the commentators - be they demographers, sociologists or economists - the Cassandras the public so much laments. With hindsight Malthus' blind spot was his neglect of technical progress. Perhaps current-day observers have become doomsayers who are impaired by the same blind spot and fail to see the possibilities of ICT-technology which may connect and solve the divergent needs of a demographically divided world. 
In a globalizing world, no country is an island and the demographic developments outside a country can be just as important as the local developments. Population aging is a global phenomenon. However, the differences in speed of aging are of importance in economic development. Europe and Japan are the 'leaders' in terms of population aging. All other continents will follow but may not reach the levels of Europe and Japan the next few decades. African population aging will mainly occur after 2050. This set of circumstances can have substantial consequences for convergence of economic development. In this final section we will summarize the most prominent consequences of an aging world in relation to the question of economic convergence:

- Demographic convergence does not necessarily imply economic convergence. Demographic factors offer a potential for catching up, whereby Africa and India can benefit from the demographic dividend implied by the demographic transition and the developed world can potentially experience the loss of this dividend. However, the demographic dividend offers only a growth potential. Whether these gains and losses are realized depends very much on the level capital accumulation, innovation and social infrastructure. Furthermore, the expected decline of fertility in the developing world may well be wishful projection. The interaction between fertility and human capital is a close one and in predicting the future course of fertility understanding this nexus better is of importance as it could destroy the supposed convergence of demographic developments.

- Migration offers no structural solution to aging populations in the North nor to a reduction of poverty in the South. To stop the population aging process countries would need excessively high levels of immigration which will in due time make integration of immigrants difficult and also increase the population density in host countries substantially. Migration can at most dampen the transitional effects of aging. Of course, this view and conclusion are mainly based on taking a purely demographic stand. Does an economic viewpoint help? Migration has been seen by some as the solution to many problems. Movement of human capital is in this view a substitute for the movement of physical capital and by the same logic of capital movements, reaping the benefits of diverging returns on investment, so can labor movement reap the benefits of diverging wages. However, the circumstances under which everyone - the country of destination and source and the migrant himself or herself - will benefit from migration are rare (Galor, 1986). Much depends on initial circumstances in both the source and destination country. Furthermore, migration generates multifaceted problems and opportunities that transcend 
the simple economics of migration because it involves the movement of persons who have their own norms and values. Adapting to new circumstances is a difficult and long-lasting process, which could take many generations (Borjas, 1999). Furthermore, the consequences of ethnic heterogeneity can be large. Ethnic heterogeneity plays a role at two levels: migration and economic growth. Immigration is often seen as the silver bullet for aging countries, but in the process advocates have forgotten how ethnic diversity can hamper integration of immigrants. Furthermore, ethnic diversity is pinpointed by some (see, e.g., Easterly and Levine, 1997) as the prime reason why Africa's economic growth record is so poor. Ethnic diversity makes cooperation more difficult and in turn leads to worse policies. However, the final verdict on the pros and cons of ethnic diversity has still to be given as there are also hopeful signs that a culture of diversity can promote growth but so far it is only theory and not practice (cf. Alesina and Le Ferrara, 2005).

- Global collective action is wound up in problems of its own design. The catching up in 'emigration' countries or regions is of interest to both destination and source countries. A convergence of economic development is not within reach for a number of decades as the less developed countries lack the social infrastructure to prosper and catch up with OECD countries. One cannot expect capital to flow from rich countries to poor countries as long as the real engines of growth are not in place (cf. Lucas, 1990). To attain this process one cannot put one's sole hope on remittances as these are not primarily used for the finance of public goods on a national scale. Official Development Assistance (ODA) and FDI may offer more hope in principle. ODA has, however, in the recent past not proven to be the silver bullet for developing countries. As Easterly remarks: “There is no Next Big Idea that will make the small amount of foreign aid the catalyst for economic growth of the world's poor nations.” (2003: 40). The organization of global collective action needs to be taken seriously (see Sandler, 2004). Foreign aid is at the moment tangled up with too many moral hazard problems to make it a credible long-run solution. At the same time one has to realize that one has to act in order to alleviate pressing problems of hunger and the destructive forces of nature and man (terrorism, global warming). Perhaps, the most sustainable solution is to offer capital flows in which the developed world participates directly in the interests of the developing world, in other words besides investing in private ventures there should also be financial participation in public goods.

These perspectives leave us with the conundrum of population and development. Are there no stones left unturned? The pressure of migration to the EU and US from neighboring regions 
can be expected to increase substantially. Remittances, FDI and ODA will remain necessary for the near future, but only FDI together with a breakdown of trade barriers can offer a sustainable world economy in the long run. It is always tempting to conjure up a solution which merges the best of all possible worlds, but such solutions will generally defy the harsh fact that free lunches for resolving such fundamental differences are not widespread. Lately, migration is seen as as the silver bullet solution because it not only smooths population decline but the remittances sent back home by far surpass the amounts which OECD/DAC members generate in terms of Official Development Assistance. Undoubtedly remittances have their beneficial effects on the welfare of people as they offer some insurance against poverty, but it is too early to say that remittances (and thereby migration) offers a superior means of offering development assistance. Remittances flow to a selective group of families and one can question the benefits that flow from remittances for the population at large as the allocation of these funds flow more to consumption than to investment purposes (cf. Chami et al. 2005). The key to sustained growth and convergence in economic development in the end have to be found in the private hands of citizens themselves. Development aid can at best help some poor people some of the time. The global collective action problems are too complex and the willingness to contribute too unbalanced to become effective.

\section{References}

Adams, R. H. and J. Page. 2005, Do International Migration and Remittances Reduce Poverty in Developing Countries?, World Development, 33: 1645-1669.

Alesina, A., and E. La Ferrara, 2005, Ethnic Diversity and Economic Performance, Journal of Economic Literature, 38: 762-800.

Amiti, M., and S.J. Wei, 2005, Fear of Service Outsourcing: Is it Justified?, Economic Policy, 307-347.

Barro, R.J., and J.W. Lee, 2005, IMF Programs: Who is Chosen and What are the Effects? Journal of Monetary Economics, 52: 1245-1269.

Beine, M., F. Docquier, and H. Rapoport, 2003, Brain Drain and LDC’s Growth: Winners and Losers, IZA Discussion Paper, no. 819, Bonn.

Boeri, T., G. Hanson, and B. McCormick (eds.), 2002, Immigration Policy and the Welfare System, Oxford University Press, Oxford.

Blanc, A.K., and A.O. Tsui, 2005, The Dilemma of Past Success: Insiders' Views on the Future of the International Family Planning Movement, Studies in Family Planning, 36: 263-276. 
Bloom, D.E. and D. Canning, 2004, Global Demographic Change: Dimensions Economic Significance, Paper presented to the Jackson Hole symposium, Federal Bank of St Louis.

Bloom, D.E., D. Canning, and B. Graham, 2003, Longevity and Life-Cyle Savings, Scandinavian Journal of Economics, 105: 319-338.

Bloom, D.E., and Williamson, J.G., 1998, Demographic Transitions and Economic Miracles in Emerging Asia, World Bank Economic Review, 12: 419-455.

Bongaarts, J., 2003, Completing the Fertility Transition in the Developing World: The Role of Educational Differences and Fertility Preferences, Population Studies, 57: 321-336.

Borjas, G.J., 1999, Heaven’s Door, Princeton University Press, New Jersey.

Boucekkine, R., D. de la Croix, and O. Licandro, 2002, Vintage Human Capital, Demographic Trends, and Endogenous Growth, Journal of Economic Theory, 104: 340-375.

Chami, R., C. Fullenkamp, and S. Jahjah. 2005. Are Immigrant Remittance Flows a Source of Capital for Development?, IMF Staff Papers 52(1): 55-81.

Chiswick, B.R., and T.J. Hatton, 2002, International Migration and the Integration of Labor Markets, IZA Discussion Paper, no. 559, Bonn.

Cleland, J., and S. Sinding, 2005, What Would Malthus say about AIDS in Africa?, The Lancet, 366: 1899-901

Coleman, D., 2000, Who's Afraid of Low Support Ratios? A UK Response to the UN Population Division Report on 'Replacement Migration', University of Oxford.

Crossette, B., 2005, Reproductive Health and the Millennium Development Goals: The Missing Link, Studies in Family Planning, 36: 71-79.

Demeny, P., 2004, Population Futures for the Next Three Hundred Years: Soft Landing or Surprises to Come?, Population and Development Review, 30: 507-517.

Drezner, D.W., 2004, The Outsourcing Bogeyman, Foreign Affairs, 83: 22-34.

Easterly, W., 2003, Can Foreign Aid Buy Growth?, Journal of Economic Perspectives, 17: 23-48.

Easterly, W. and R. Levine, 1997, Africa’s Growth Tragedy: Policies and Ethnic Divisions, Quarterly Journal of Economics, 112: 1203-1250.

Galor, O., 1986, Time Preference and International Labor Migration, Journal of Economic Theory, 38: 1-20.

Gould, D.M., 1994, Immigrant Links to the Home Country: Empirical Implications for U.S. Bilateral Trade Flows, Review of Economics and Statistics, 76: 302-316. 
Hall, R.E., and C.I. Jones, 1999, Why Do Some Countries Produce So Much More Output per Worker Than Others?, Quarterly Journal of Economics, 114: 83-116.

Hamilton, B. and J.Walley, 1984, Efficiency and Distributional Implications of Global Restrictions on Labour Mobility: Calculations of Policy Implications, Journal of Development Economics, 14: 61-75.

Harrison, A., 2004, Working Abroad - The Benefits Flowing from Nationals Working in Other Economies, OECD, Paris.

Hatton, T.J., and J.G. Williamson, 2002, Out of Africa? Using the Past to Project African Emigration Pressure in the Future, Review of International Economics, 10: 556-573.

Hatton, T.J., and J.G. Williamson, 2003, Demographic and Economic Pressure on Emigration Out of Africa, Scandinavian Journal of Economics, 105: 465-486.

Hatton, T.J., and J.G. Williamson, 2004, International Migration in the Long-Run: Positive Selection, Negative Selection and Policy, NBER Working Paper, no. 10529, Cambridge, MA.

Helliwell, J.F., 2004, Demographic Change and International Factor Mobility, NBER working paper, no. 10945, Cambridge MA.

International Monetary Fund (IMF), 2005, World Economic Outlook 2005, Washington DC.

Iregui, A.M., 2005, Efficiency Gains from the Elimination of Global Restrictions on Labour Mobility: An Analysis Using Multregional CGE Models, in: G.J. Borjas and J. Crisp (eds.), Poverty, International Migration and Asylum, Palgrave MacMillan, New York, pp. 211-238.

Jayaraman, R., and R. Kanbur, 1999, International Public Goods and the Case for Foreign Aid, in: I. Kaul, I. Grunberg and M.A. Stern (Eds.), Global Public Goods, Oxford University Press, Oxford, pp. 418-435.

Kaul, I., P. Conceicao, K. Le Goulven, and R.U. Mendoza (eds.), 2003, Providing Global Public Goods - Managing Globalization, Oxford University Press, Oxford.

Leamer, E.E., and M. Storper, 2001, The Economic Geography of the Internet Age, Journal of International Business Studies, 32: 641-665.

Lee, R.D., and S. Tuljapurkar, 1997, Death and Taxes: Longer Life, Consumption, and Social Security, Demography, 34: 67-81.

Lee, R.D., A. Mason, and T. Miller, 2003, Saving, Wealth and the Transition from Transfers to Individual Responsibility: The Cases of Taiwan and the United States, Scandinavian Journal of Economics, 105: 339-357. 
Lewis, M., 2005, Addressing the Challenges of HIV/AIDS: Macroeconomic, Fiscal and Institutional Issues, Working Paper, no. 58, Center for Global Development, Helsinki.

Lucas, R.E. Jr., 1990, Why Doesn’t Capital Flow from Rich to Poor Countries?, American Economic Review, Papers and Proceedings, 80: 92-96.

Mayda, A.M., 2004, Who is Against Immigration? A Cross-Country Investigation of Individual Attitudes towards Immigrants, IZA Discussion Paper, no. 1115, Bonn.

Maddison, A., 2005, Measuring and Interpreting World Economic Performance, 1500-2001, Review of Income and Wealth, 51: 1-35.

Merrick, T.W., 2002, Population and Poverty: New Views on an Old Controversy, International Family Planning Perspectives, 28: 41-46.

Moses, J.W., and B. Letnes, 2005, If People Were Money: Estimating Gains and Scope of Free Migration, in: G.J. Borjas and J. Crisp (eds.), Poverty, International Migration and Asylum, Palgrave MacMillan, New York, pp. 188-210.

Rajan, R.G., and A. Subramanian, 2005, Aid and Growth: What Does the Cross-Country Evidence Really Show?, NBER working paper, no. 11513, Cambridge, MA.

Ross, J., J. Stover and D. Adelaja, 2005, Profiles for Family Planning and Reproductive Health Programs, $2^{\text {nd }}$ edition, Futures Group, Glastonbury

Sala-i-Martin, X., 1996, The Classical Approach to Convergence Analysis, Economic Journal, 106: 1019-1036.

Sandler, T., 2004, Global Collective Action, Cambridge: Cambridge University Press.

Schelling, T.C., 1998, The Cost of Combating Global Warming - Facing the Tradeoffs, Foreign Affairs, 76: 8-14.

Schoorl, J. J., L. Heering, I. Esveldt, G. Groenewold, R. F. van der Erf, A. M. Bosch, H. de Valk, and B. J. de Bruijn, 2000, Push and Pull Factors of International Migration: A Comparative Report. Research Report 3/2000/E/no.14. Luxembourg: Eurostat.

Schultz, T.P., 1998, Immigrant Quality and Assimilation: A Review of the US Literature, Journal of Population Economics, 11: 239-252.

Stark, O., 2004, Rethinking the Brain Drain, World Development, 32: 15-22.

United Nations, 2000, Replacement Migration: Is It A Solution to Declining and Aging Populations, UN Population Divison, New York.

United Nations, 2004, World Population Prospects: The 2004 Revision Population Database, UN Population Divison, New York, http://esa.un.org/unpp/ 
Van Dalen, H.P., 2007, Designing Global Collective Action in Reproductive Health and AIDS Programs, 1983-2002: Has Anything Changed?, World Development, forthcoming.

Van Dalen, H.P., G. Groenewold, and T. Fokkema, 2005, The Effect of Remittances on Emigration Intentions in Morocco, Egypt and Turkey, Population Studies, 59: 375392.

Van Dalen, H.P., G. Groenewold and J.J. Schoorl, 2005, Out of Africa: What Drives the Pressure to Emigrate?, Journal of Population Economics, 18: 741-778.

Van Dalen, H.P., and K. Henkens, 2005, The Rationality Behind Immigration Policy Preferences, De Economist, 153: 67-83.

Van Dalen, H.P. and M. Reuser, 2005, Assessing the Size and Structure of World Wide Funds for Population and AIDS activities, NIDI, The Hague, www.resourceflows.org.

World Bank, 2004a, Global Development Finance 2004, Washington DC: World Bank, Retrieved from http://web.worldbank.org.

World Bank, 2004b, World Development Report - Making Services Work for Poor People, Oxford University Press, Oxford.

Zimmermann, K.F. (ed.), 2005, European Migration - What Do we Know?, Oxford University Press, Oxford. 
Figure 1: Change in Life expectancy, 1950-2050

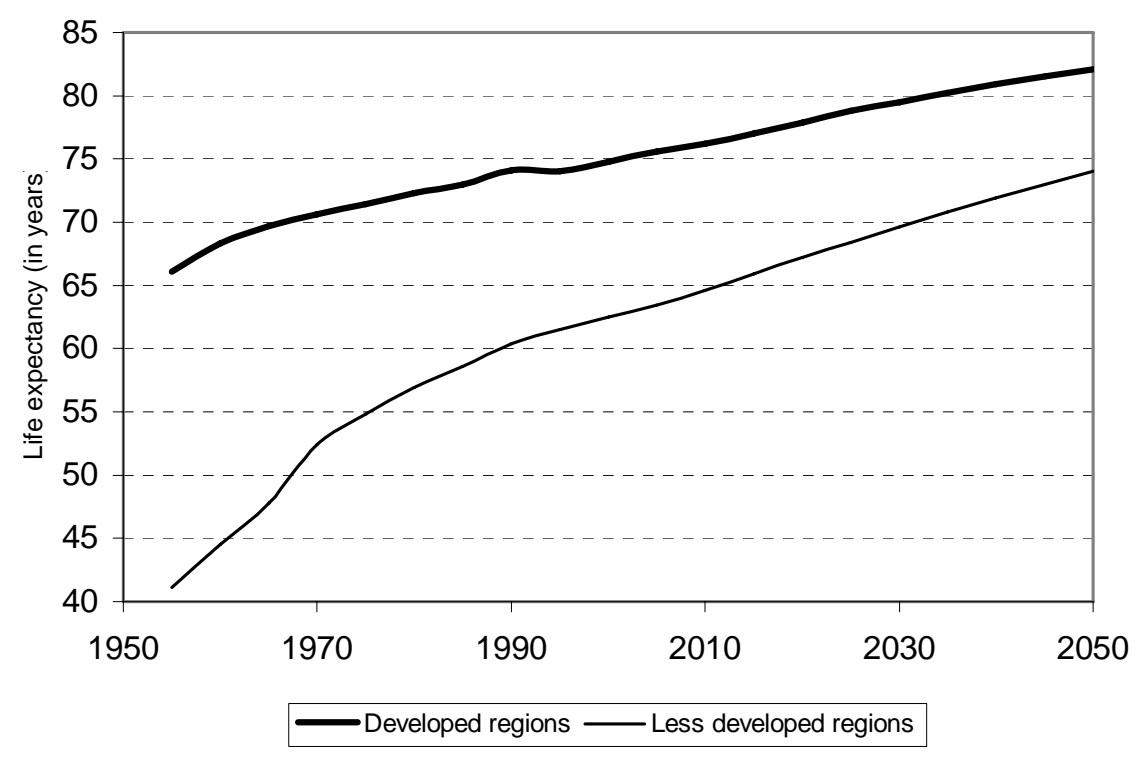

Source: UN (2004) projections

Figure 2: Total fertility in main regions of the world, 1950-2050

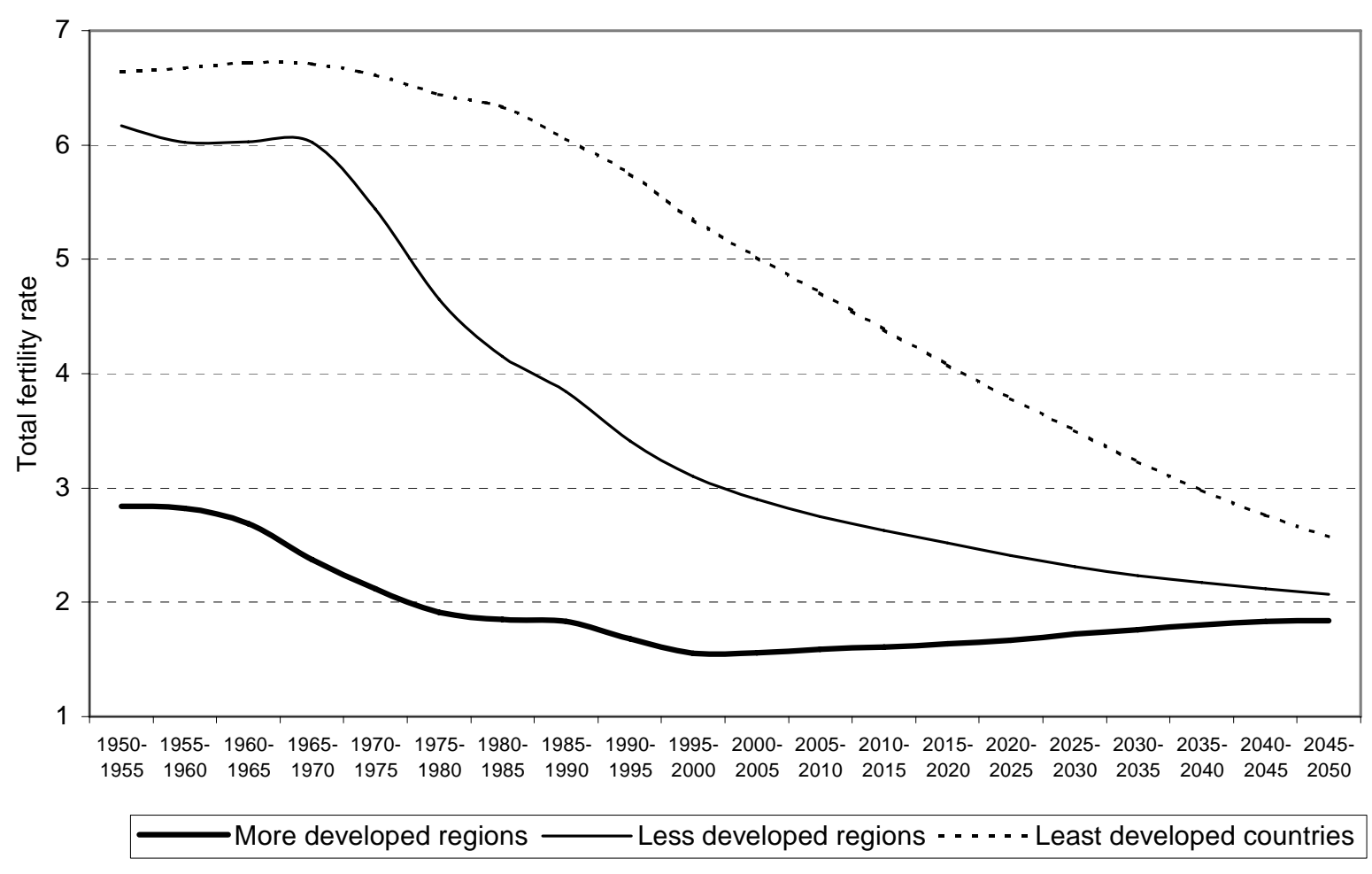

Source: UN (2004) projections 
Figure 3: Working-age population (15-64 age group as percentage of total) in international perspective

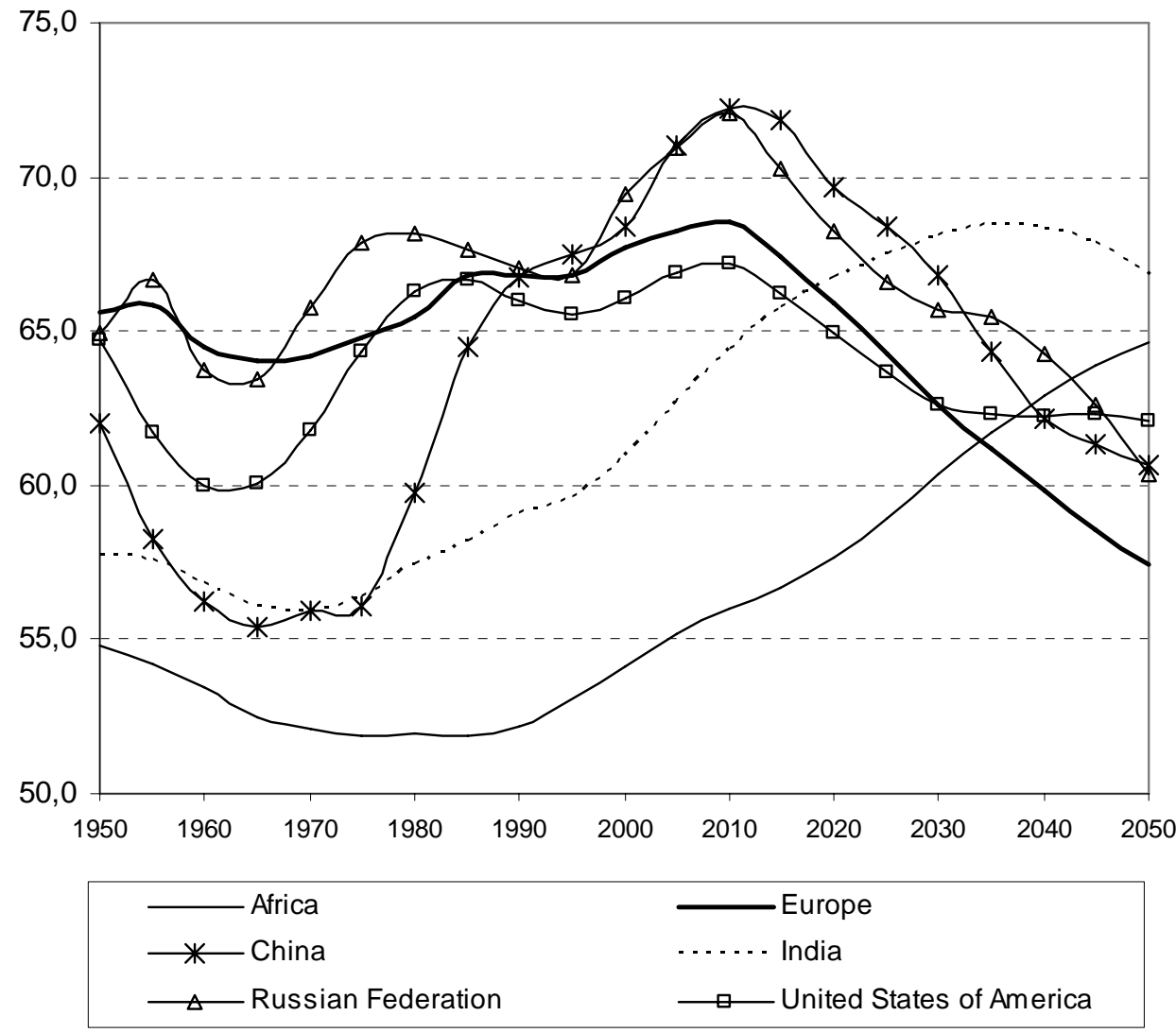

Source: UN (2004) projections 
Figure 4: The median age of populations in the world, 1950-2050

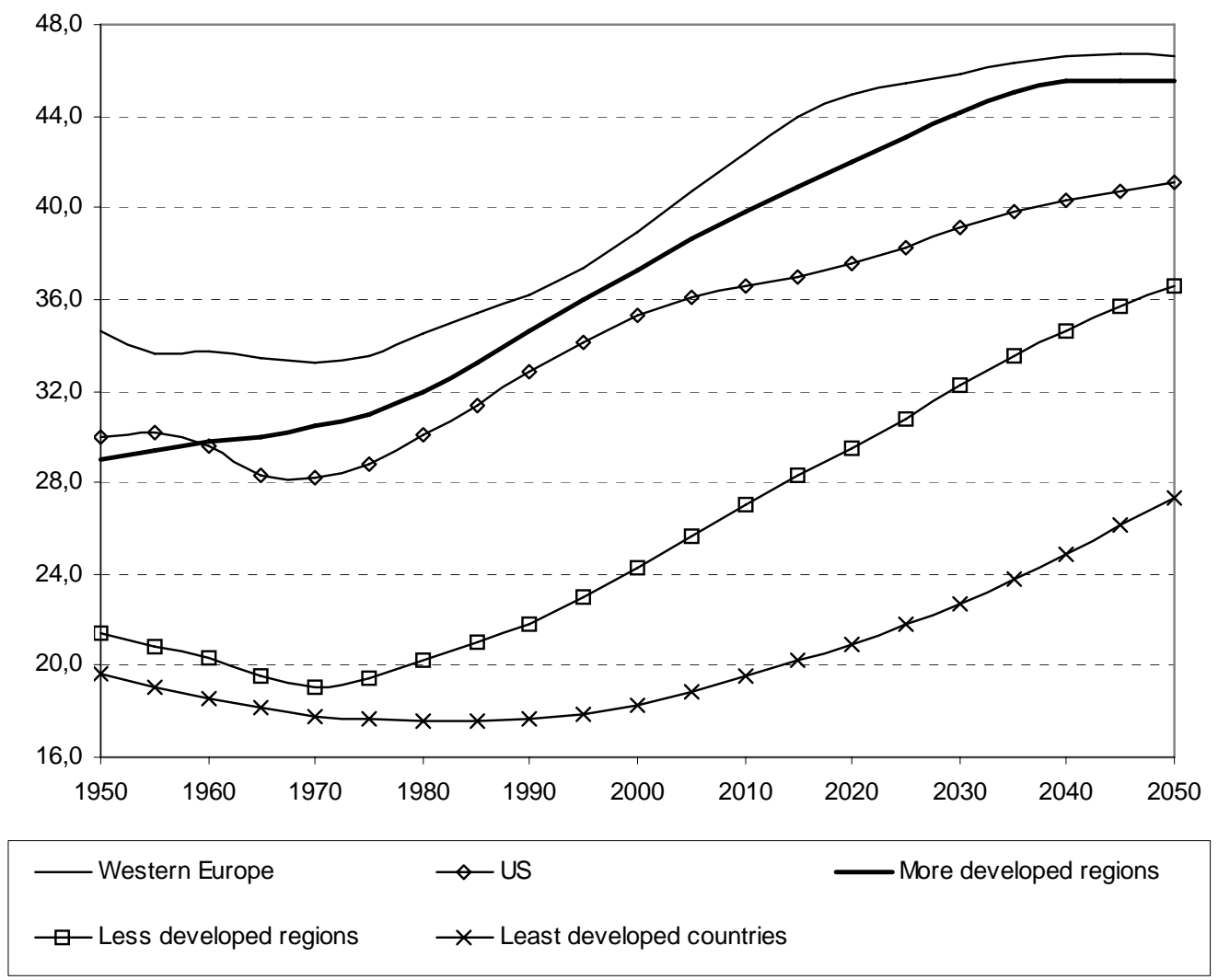

Source: UN (2004) projections 
Figure 5: Development of primary funds on population assistance programs, 1970-2005 (million US dollars)

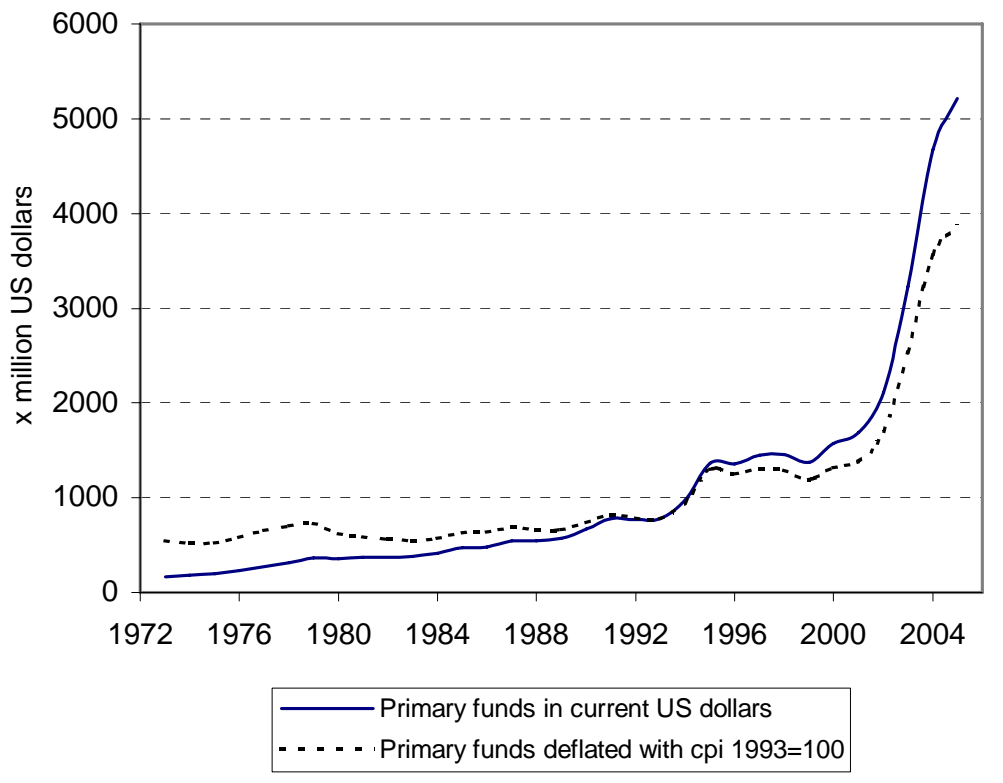

Source: Van Dalen and Reuser (2005) 
Figure 6: Workers' Remittances and Other Capital Flows to Developing Countries, 1970-2003 (in billion US dollars)

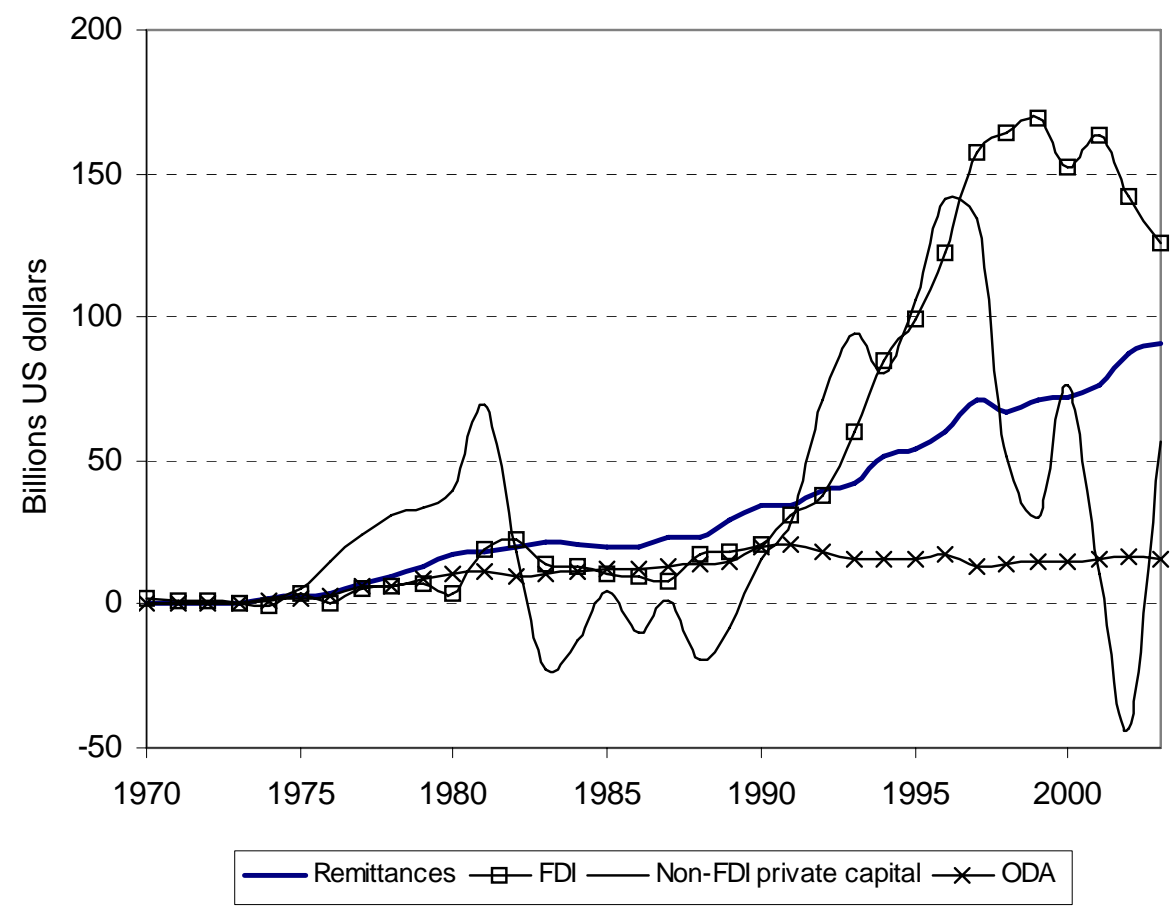

Source: IMF, World Economic Outlook (2005, p. 70). 
Table 1: Proportions of Demand Satisfied by Modern Contraceptive Use by Wealth Quintile (Q1 poorest, Q5 wealthiest), unweighted averages for selected countries within region

\begin{tabular}{lllllllc}
\hline & Period & Q1 & Q2 & Q3 & Q4 & Q5 & All quintiles \\
\hline Africa & $1990-1995$ & 12.9 & 16.0 & 17.7 & 24.7 & 36.9 & 22.9 \\
& $1996-2000$ & 23.7 & 25.2 & 29.1 & 37.2 & 48.0 & 33.9 \\
Latin America & $1990-1995$ & 29.4 & 40.7 & 49.0 & 57.4 & 65.3 & 50.0 \\
& $1996-2000$ & 38.1 & 48.8 & 57.3 & 61.7 & 68.0 & 56.4 \\
Asia & $1990-1995$ & 48.2 & 51.0 & 57.5 & 57.5 & 67.6 & 57.1 \\
& $1996-2000$ & 50.0 & 57.1 & 59.8 & 63.7 & 70.7 & 60.9 \\
N. Africa/W Asia & $1990-1995$ & 36.8 & 45.7 & 53.7 & 58.2 & 65.4 & 53.8 \\
& $1996-2000$ & 49.7 & 59.0 & 62.0 & 67.5 & 70.5 & 62.7 \\
Global average & $1990-1995$ & 29.2 & 35.8 & 40.4 & 46.2 & 55.6 & 42.7 \\
& $1996-2000$ & 37.9 & 44.4 & 49.3 & 54.7 & 62.1 & 50.8 \\
\hline
\end{tabular}

Source: Bernstein (2004), cited in Ross et al. (2005: 52). 
Table 2: Explaining the number of children among ever married women ${ }^{\mathrm{a}}$

\begin{tabular}{|c|c|c|c|c|c|}
\hline & $\begin{array}{l}\text { Non- } \\
\text { OECD }\end{array}$ & EU15 & $\begin{array}{l}\text { New EU } \\
\text { members }\end{array}$ & $\begin{array}{c}\text { EU } \\
\text { candidate } \\
\text { members }\end{array}$ & $\begin{array}{c}\text { OECD } \\
\text { members } \\
\text { outside EU }\end{array}$ \\
\hline \multicolumn{6}{|l|}{ Age group $(15-29=0)$} \\
\hline $30-49$ & $\begin{array}{l}1.19 \\
(0.03)\end{array}$ & $\begin{array}{c}0.95 \\
(0.06)\end{array}$ & $\begin{array}{c}0.80 \\
(0.06)\end{array}$ & $\begin{array}{c}1.21 \\
(0.07)\end{array}$ & $\begin{array}{l}1.13 \\
(0.07)\end{array}$ \\
\hline 50 and older & $\begin{array}{l}1.77 \\
(0.03)\end{array}$ & $\begin{array}{l}1.30 \\
(0.06)\end{array}$ & $\begin{array}{c}0.83 \\
(0.07)\end{array}$ & $\begin{array}{l}1.34 \\
(0.08)\end{array}$ & $\begin{array}{l}1.66 \\
(0.07)\end{array}$ \\
\hline \multicolumn{6}{|c|}{$\begin{array}{l}\text { Marital status (married/living } \\
\text { together }=0 \text { ) }\end{array}$} \\
\hline Divorced/separated & $\begin{array}{l}-0.39 \\
(0.04)\end{array}$ & $\begin{array}{l}-0.21 \\
(0.05)\end{array}$ & $\begin{array}{l}-0.22 \\
(0.06)\end{array}$ & $\begin{array}{l}-0.57 \\
(0.13)\end{array}$ & $\begin{array}{l}-0.24 \\
(0.07)\end{array}$ \\
\hline Widowed & $\begin{array}{l}-0.14 \\
(0.03)\end{array}$ & $\begin{array}{c}0.00 \\
(0.05)\end{array}$ & $\begin{array}{l}-0.01 \\
(0.05)\end{array}$ & $\begin{array}{l}-0.14 \\
(0.08)\end{array}$ & $\begin{array}{c}0.33 \\
(0.08)\end{array}$ \\
\hline \multicolumn{6}{|l|}{ Education (lower $=0$ ) } \\
\hline Middle & $\begin{array}{l}-0.67 \\
(0.02)\end{array}$ & $\begin{array}{l}-0.26 \\
(0.04)\end{array}$ & $\begin{array}{l}-0.35 \\
(0.04)\end{array}$ & $\begin{array}{l}-0.78 \\
(0.06)\end{array}$ & $\begin{array}{l}-0.45 \\
(0.06)\end{array}$ \\
\hline Upper & $\begin{array}{l}-1.01 \\
(0.03)\end{array}$ & $\begin{array}{l}-0.37 \\
(0.05)\end{array}$ & $\begin{array}{l}-0.49 \\
(0.06)\end{array}$ & $\begin{array}{l}-1.03 \\
(0.09)\end{array}$ & $\begin{array}{l}-0.60 \\
(0.07)\end{array}$ \\
\hline \multicolumn{6}{|l|}{ Income $($ lower $=0$ ) } \\
\hline Middle & $\begin{array}{l}-0.06 \\
(0.02)\end{array}$ & $\begin{array}{l}-0.06 \\
(0.04)\end{array}$ & $\begin{array}{l}-0.06 \\
(0.05)\end{array}$ & $\begin{array}{l}-0.18 \\
(0.06)\end{array}$ & $\begin{array}{l}-0.20 \\
(0.05)\end{array}$ \\
\hline Upper & $\begin{array}{l}-0.11 \\
(0.03)\end{array}$ & $\begin{array}{l}-0.09 \\
(0.05)\end{array}$ & $\begin{array}{l}-0.09 \\
(0.05)\end{array}$ & $\begin{array}{l}-0.24 \\
(0.08)\end{array}$ & $\begin{array}{l}-0.26 \\
(0.06)\end{array}$ \\
\hline \multicolumn{6}{|c|}{$\begin{array}{l}\text { Importance of religion in your life } \\
\text { (very important }=0) \text { : }\end{array}$} \\
\hline Rather important & $\begin{array}{l}-0.12 \\
(0.03)\end{array}$ & $\begin{array}{l}-0.16 \\
(0.04)\end{array}$ & $\begin{array}{l}-0.17 \\
(0.05)\end{array}$ & $\begin{array}{l}-0.13 \\
(0.07)\end{array}$ & $\begin{array}{l}-0.23 \\
(0.06)\end{array}$ \\
\hline Not very important & $\begin{array}{l}-0.19 \\
(0.04)\end{array}$ & $\begin{array}{l}-0.25 \\
(0.05)\end{array}$ & $\begin{array}{l}-0.13 \\
(0.06)\end{array}$ & $\begin{array}{l}-0.20 \\
(0.10)\end{array}$ & $\begin{array}{l}-0.38 \\
(0.06)\end{array}$ \\
\hline Not at all important & $\begin{array}{l}-0.16 \\
(0.05)\end{array}$ & $\begin{array}{l}-0.34 \\
(0.05)\end{array}$ & $\begin{array}{l}-0.14 \\
(0.06)\end{array}$ & $\begin{array}{l}-0.26 \\
(0.13)\end{array}$ & $\begin{array}{l}-0.49 \\
(0.08)\end{array}$ \\
\hline Constant & $\begin{array}{c}1.84 \\
(0.06)\end{array}$ & $\begin{array}{l}1.85 \\
(0.11)\end{array}$ & $\begin{array}{l}2.19 \\
(0.10)\end{array}$ & $\begin{array}{c}1.71 \\
(0.11)\end{array}$ & $\begin{array}{l}2.29 \\
(0.12)\end{array}$ \\
\hline Country dummies & Yes & Yes & Yes & Yes & Yes \\
\hline $\begin{array}{l}\mathrm{N}= \\
\text { Adj. } \mathrm{R}^{2}\end{array}$ & $\begin{array}{c}21,256 \\
0.31\end{array}$ & $\begin{array}{c}6,749 \\
0.16\end{array}$ & $\begin{array}{c}3,556 \\
0.14\end{array}$ & $\begin{array}{c}2,996 \\
0.28\end{array}$ & $\begin{array}{c}4,130 \\
0.25\end{array}$ \\
\hline
\end{tabular}

(a) Standard errors are stated within brackets. Source data: World Values Survey, 2000-2001 
Table 3: Absolute change in world population by main age groups, (in millions) over 25 year periods

\begin{tabular}{|c|c|c|c|c|}
\hline & \multicolumn{4}{|c|}{ Absolute change in world population for time period: } \\
\hline & $1950-1975$ & $1975-2000$ & $2000-2025$ & $2025-2050$ \\
\hline Total & 1,554 & 2,012 & 1,820 & 1,171 \\
\hline \multicolumn{5}{|c|}{ Age structure of this change } \\
\hline \multicolumn{5}{|c|}{ Age group } \\
\hline $0-14$ & 40.8 & 16.4 & 4.5 & -6.5 \\
\hline $15-24$ & 19.2 & 15.6 & 7.7 & 1.2 \\
\hline $25-64$ & 33.6 & 58.6 & 65.3 & 51.3 \\
\hline $65-74$ & 4.2 & 5.5 & 13.6 & 22.3 \\
\hline \multirow[t]{2}{*}{$75+$} & 2.3 & 3.9 & 8.9 & 31.8 \\
\hline & 100 & 100 & 100 & 100 \\
\hline
\end{tabular}

Source: UN (2004) projections 
Table 4: GDP per capita in the world and major regions, 1500-2001 (in 1990 international dollars)

\begin{tabular}{lccccccc}
\hline & 1500 & 1820 & 1870 & 1913 & 1950 & 1973 & 2001 \\
\hline Western Europe & 771 & 1204 & 1960 & 3458 & 4579 & 11416 & 19256 \\
US, Canada, Australia en New Zealand & 400 & 1202 & 2419 & 5233 & 9268 & 16179 & 26943 \\
Japan & 500 & 669 & 737 & 1387 & 1921 & 11434 & 20683 \\
West & 702 & 1109 & 1882 & 3672 & 5649 & 13082 & 22509 \\
Asia (excl. Japan) & 572 & 577 & 550 & 658 & 634 & 1226 & 3256 \\
Latin America & 416 & 692 & 681 & 1481 & 2506 & 4504 & 5811 \\
Eastern Europe and Russia & 498 & 686 & 941 & 1558 & 2602 & 5731 & 5038 \\
Africa & 414 & 420 & 500 & 637 & 894 & 1410 & 1489 \\
Rest & 538 & 578 & 606 & 860 & 1091 & 2072 & 3377 \\
World & 566 & 667 & 875 & 1525 & 2111 & 4091 & 6049 \\
& & & & & & & \\
Ratio West/Africa & 1.7 & 2.6 & 3.8 & 5.8 & 6.3 & 9.3 & 15.1 \\
Ratio West/Rest & 1.3 & 1.9 & 3.1 & 4.3 & 5.2 & 6.3 & 6.7 \\
\hline
\end{tabular}

Source: Maddison (2005: 11)

Table 5: Pattern of migration flows in the world (in million persons), 2000

\begin{tabular}{lccccccc}
\hline \multicolumn{7}{c}{ Migrants coming from: } \\
\hline Going to: & Africa & Asia & Europe & Latin America* & North America & Oceania & Total \\
Africa & 11.5 & 0.4 & 0.2 & 0.0 & 0.0 & 0.0 & 12.2 \\
Asia & 2.0 & 34.9 & 3.2 & 0.4 & 0.3 & 0.1 & 40.8 \\
Europe & 2.3 & 4.1 & 34.9 & 0.4 & 0.4 & 0.1 & 42.1 \\
Latin America* & 0.0 & 0.1 & 1.7 & 2.9 & 0.4 & 0.0 & 5.2 \\
North America & 0.7 & 8.3 & 6.2 & 14.7 & 1.0 & 0.1 & 31.0 \\
Oceania & 0.3 & 1.5 & 2.7 & 0.0 & 0.2 & 0.7 & 5.3 \\
\hline Total & 16.8 & 49.3 & 48.9 & 18.3 & 2.3 & 1.0 & 136.7 \\
\hline
\end{tabular}

* Latin America includes the Caribbean

Source: Harrison (2004) 
Table 6: Primary funds to population and AIDS activities from international foundations, 1996-2007

\begin{tabular}{|c|c|c|c|c|c|c|}
\hline \multirow{3}{*}{ Year } & \multirow{2}{*}{$\begin{array}{c}\text { General } \\
\text { unearmarked } \\
\text { contributions }\end{array}$} & \multicolumn{4}{|c|}{ Earmarked funds flowing to: } & \multirow[t]{2}{*}{ Total Funds } \\
\hline & & $\begin{array}{c}\text { Family } \\
\text { Planning }\end{array}$ & $\begin{array}{l}\text { Reproductive } \\
\text { Health }\end{array}$ & STD/HIV/AIDS & Basic Research & \\
\hline & \multicolumn{5}{|c|}{ Allocation across categories in percentages } & Million US \$ \\
\hline 1996 & 23.0 & 8.2 & 26.3 & 10.7 & 31.8 & $1,369.1$ \\
\hline 1997 & 26.3 & 10.1 & 22.1 & 11.3 & 30.3 & $1,529.9$ \\
\hline 1998 & 10.2 & 15.9 & 37.9 & 12.2 & 23.8 & $1,538.8$ \\
\hline 1999 & 35.5 & 10.3 & 36.1 & 9.1 & 8.9 & $1,411.1$ \\
\hline 2000 & 1.8 & 11.3 & 48.0 & 33.2 & 5.7 & $1,597.7$ \\
\hline 2001 & 7.2 & 7.1 & 48.3 & 33.9 & 3.5 & $1,719.7$ \\
\hline 2002 & 8.0 & 7.3 & 18.6 & 56.3 & 9.8 & 2,313.9 \\
\hline 2003 & 8.6 & 9.7 & 28.9 & 45.0 & 7.7 & $3,737.7$ \\
\hline 2004 & 23.1 & 7.1 & 14.7 & 49.1 & 5.9 & $5,578.4$ \\
\hline $2005 *$ & 6.1 & 2.5 & 7.6 & 80.3 & 3.5 & $5,818.0$ \\
\hline 2006* & 6.0 & 2.2 & 7.1 & 81.6 & 3.1 & $6,659.3$ \\
\hline $2007 *$ & 5.4 & 1.7 & 5.9 & 84.8 & 2.2 & $7,421.6$ \\
\hline
\end{tabular}

* Projections

Source: NIDI/UNFPA/UNAIDS

Table 7: Pattern of remittance flows in the world (in billion US dollars), 2000

\begin{tabular}{lccccccc}
\hline \multicolumn{7}{c}{ Remittances going to } \\
\hline Coming from: & Africa & Asia & Europe & Latin America & North America & Oceania & Total \\
Africa & 3.7 & 0.5 & 0.1 & 0.0 & 0.0 & 0.0 & 4.2 \\
Asia & 3.4 & 31.5 & 3.4 & 0.5 & 0.2 & 0.0 & 39.0 \\
Europe & 2.6 & 3.2 & 9.5 & 0.4 & 0.4 & 0.1 & 16.2 \\
Latin America & 0.0 & 0.1 & 0.6 & 1.1 & 0.1 & 0.0 & 1.8 \\
North America & 0.7 & 7.9 & 5.7 & 14.2 & 0.9 & 0.1 & 29.6 \\
Oceania & 0.0 & 0.2 & 0.4 & 0.0 & 0.0 & 0.1 & 0.8 \\
\hline Total & 10.4 & 43.4 & 19.6 & 16.2 & 1.6 & 0.3 & 91.5 \\
\hline
\end{tabular}

* This table excludes \$24.1 billion for European border workers.

Source: Harrison (2004) 